\title{
Short communication: Evaluation of nitrogen excretion equations from cattle
}

A. C. B. Johnson, K. F. Reed, and E. Kebreab ${ }^{1}$

Department of Animal Science, University of California, Davis 95616

\begin{abstract}
Nitrogen excretion in dairy manure is a precursor for $\mathrm{N}_{2} \mathrm{O}$ and $\mathrm{NH}_{3}$ formation in livestock housing, manure storage facilities, and after manure is applied to land. Nitrous oxide is a major contributor to greenhouse gas emissions, and reducing $\mathrm{N}$ output from dairy production facilities can reduce the amount of anthropogenic $\mathrm{N}_{2} \mathrm{O}$ entering the atmosphere. The objective of the study was to conduct a comprehensive evaluation of extant prediction models for $\mathrm{N}$ excretion in feces and urine using extensive literature data. A total of $45 \mathrm{~N}$ excretion equations were evaluated for lactating cows, heifers, and nonlactating cows and steers. These equations were evaluated with 215 treatment means from 69 published studies collected over 20 yr from 1995 to 2015. Two evaluation methods were used: the root mean square prediction error and the concordance correlation coefficient. Equations constructed using a more rigorous development process fared better than older extant equations. Equations for heifers and nonlactating cows had greater error of prediction compared with equations used for lactating cows. This could be due to limited amount of data available for construction and evaluation of the equations. Urinary $\mathrm{N}$ equations had greater prediction errors than other forms of excretion, possibly due to high variability in urinary $\mathrm{N}$ excretion and challenges in urine collection. Fecal $\mathrm{N}$ equations had low error bias and reached an acceptable level of precision and accuracy.
\end{abstract}

Key words: empirical equation, nitrogen utilization, cattle

\section{Short Communication}

Livestock $\mathrm{N}$ emissions are one of the leading contributors to $\mathrm{NH}_{3}$ and $\mathrm{N}_{2} \mathrm{O}$ emissions in the United States (Davidson, 2009). Cattle operations, in particular beef and dairy, account for the majority of emissions, respectively contributing 41 and $20 \%$ of total livestock emis-

Received December 7, 2015

Accepted April 30, 2016.

${ }^{1}$ Corresponding author: ekebreab@ucdavis.edu sions (Gerber et al., 2013). In addition to $\mathrm{N}_{2} \mathrm{O}$ escape, manure $\mathrm{N}$ can contribute to eutrophication of surface waters through runoff and acid rain (McCubbin et al., 2002; Diaz and Rosenberg, 2008); over-fertilization of soils can impair crop growth; and $\mathrm{NH}_{3}$ and nitrate emissions can lead to formation of particulate matter, which forms when $\mathrm{NH}_{3}$ combines with nitrates and sulfates to form fine particulates (Fowler et al., 2013). The surplus of anthropogenic $\mathrm{N}$ compounds in the atmosphere has a detrimental effect on the environment and is linked to significant human health problems including odor problems, lung diseases, chronic bronchitis, and premature mortality (McCubbin et al., 2002; Fowler et al., 2013). As the human population continues to rise, the demand for meat and dairy products will continue to increase, and the challenge is to meet this demand while minimizing damage to the environment.

Mitigation strategies to reduce the amount of $\mathrm{N}$ lost to the environment from cattle production systems fall into 2 broad categories: (1) feeding strategies to reduce the amount of $\mathrm{N}$ excreted by the dairy cow per unit of milk or meat produced, and (2) manure management strategies to reduce the amount of $\mathrm{N}$ lost during storage and land application. To assess effectiveness of strategies to reduce negative environmental effect requires quantification of nutrient losses under different management alternatives. Widely used $\mathrm{N}$ excretion prediction equations include international, national, and regional approaches for estimating greenhouse gas emissions. Most countries use the Intergovernmental Panel on Climate Change (IPCC) Tier 1 or 2 default values to report total N (TN) excretion, which are scalar multipliers of the total animal mass (IPCC, 2006). In the US National Greenhouse Gas Inventory, the US Environmental Protection Agency (EPA) estimates $\mathrm{TN}$ as the difference between total $\mathrm{N}$ intake (NI) and the sum of estimated secreted milk $\mathrm{N}(\mathbf{M N})$ and $\mathrm{N}$ retained in animal tissue (EPA, 2014). Fecal (FN) and urinary $\mathrm{N}(\mathbf{U N})$ excretions have different effects on the environment, so equations predicting UN and FN separately improve estimation of $\mathrm{N}$ partitioning to air and soil. Several equations have been developed to estimate FN and UN excretion separately and have been reported to improve the accuracy of estimation 
Table 1. Summary of nitrogen data collected from 1995 to 2015 by animal class

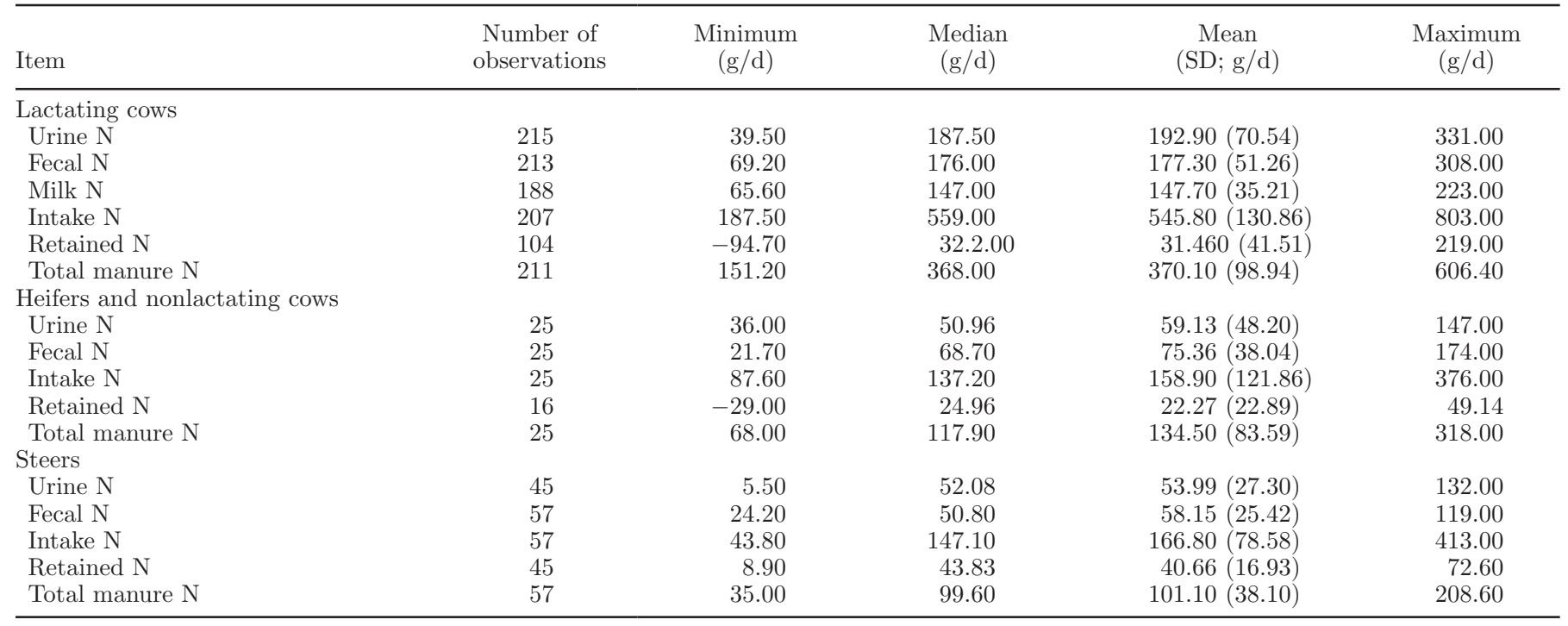

(Reed et al., 2015b). Most extant equations predicting $\mathrm{N}$ excretion from cattle were developed from a small pool of potential covariates and selected based on either biological knowledge or a stepwise selection method, both of which are subject to criticism. A more rigorous equation development strategy and thorough search of available covariates and equation parameter space is likely to improve prediction ability. However, when the number of possible covariates is large, equation selection can be a time- and computation-intensive process. The genetic algorithm used by Reed et al. (2015b) facilitated the selection process and reduced the time required to identify the best possible equation based on a given criteria. Although the equations developed by Reed et al. (2015b) performed well in internal evaluation, the most recent observation in the data used for equation development and evaluation was collected in 1994, so the prediction accuracy of the equations for modern cows is uncertain. Thus, the objective of this study was to evaluate the accuracy and precision of existing $\mathrm{N}$ excretion prediction equations for 3 animal classes and 3 forms of $\mathrm{N}$ excretion using $\mathrm{N}$ balance data collected from recently published studies.

Published data from the National Center for Biotechnology Information (PubMed) and BIOSIS were collected using the key phrase "nitrogen utilization and excretion from dairy cattle" and from additional searches including the words "steers," "lactating cows," "heifers," and "non-lactating cows." Manuscripts were selected if the title or abstract of the article included any or all of the key words "nitrogen," "dairy," and "fecal/urine." Data collection was limited to studies published between 1994 and 2015 to ensure current data were used for evaluation. Data were collected for 3 animal classes, lactating cows, heifers and nonlactating cows, and steers, to be able to evaluate equations for the 3 animal classes reported by Reed et al. (2015b). The majority of articles collected did not report the ME content of the feed, which is a predictor in several of the equations being evaluated. If diet $\mathrm{ME}$ was not provided by the study and if $95 \%$ or greater of the ME values of the ingredients were either reported or available in nutrient composition tables, diet ME was calculated using the summative approach described in the NRC (2001). A total of 69 studies were collected, which covered lactating cows $(\mathrm{n}=57)$, heifer and nonlactating cows $(\mathrm{n}=6)$, and steers $(\mathrm{n}=13)$, resulting in 215,23 , and 57 treatment means, respectively (Table 1). A list of the references used for data collection is provided in Table 2 .

The equations evaluated were listed by Reed et al. $(2015 \mathrm{a}, \mathrm{b})$. An additional literature search was conducted to add to the total number of equations, resulting in 46 equations (Table 3 ). For each animal class, equations predicting fecal, urine, milk, and total manure $\mathrm{N}$ were included. Two methods were used to evaluate the equations: the root mean square prediction error (RMSPE) and the concordance correlation coefficient (CCC; Lin, 1989, 2000). The RMSPE was calculated using the following equation:

$$
\operatorname{RMSPE}=\left[(\mathbf{y}-\mathbf{X} \hat{\boldsymbol{\beta}})^{T}(\mathbf{y}-\mathbf{X} \hat{\boldsymbol{\beta}}) n^{-1}\right]^{1 / 2}
$$

where $\mathbf{y}$ is the vector of observations, $\mathbf{X}$ is the matrix of explanatory variables, $\hat{\boldsymbol{\beta}}$ is the vector of fixed-effect parameter estimates, $n$ is the number of observations in 
each fold, and the superscript $T$ denotes the transpose function. The RMSPE was decomposed into the error of central tendency, the error due to regression, and the error of dispersion as described by Bibby and Toutenburg (1977). Smaller prediction errors are more desirable, and although there are no explicit rules for the amount of acceptable error, a guideline proposed by Reed et al. (2015a) states that an RMSPE as a percentage of the mean observed value below $25 \%$ is deemed acceptable and an RMSPE below $10 \%$ of the mean is considered good. In reference to the error decomposition, mean or systemic bias larger than $5 \%$ of the total error is considered a deviation from the desired random

Table 2. List of every study used to evaluate $\mathrm{N}$ excretion equations

Study and group

$\begin{array}{ll} & \text { Lactating cows } \\ \text { Agle et al. (2010a) } & \text { Kolver et al. (1998) } \\ \text { Agle et al. (2010b) } & \text { Kamiya et al. (2005) } \\ \text { Arriaga et al. (2010) } & \text { Kauffman and St-Pierre (2001) } \\ \text { Aschemann et al. (2012) } & \text { Korhonen et al. (2002) } \\ \text { Beckman and Weiss (2005) } & \text { Kröber et al. (2000) } \\ \text { Benchaar et al. (2014) } & \text { Lapierre et al. (2002) } \\ \text { Benchaar et al. (2013) } & \text { Lee et al. (2009) } \\ \text { Borucki Castro et al. (2008) } & \text { Lee et al. (2011) } \\ \text { Castillo et al. (2001) } & \text { Leiva et al. (2000) } \\ \text { Chen et al. (2011) } & \text { Mitani et al. (2005) } \\ \text { Cherney et al. (2003) } & \text { Mitsuru et al. (2005) } \\ \text { Chibisa et al. (2008) } & \text { Miyaji et al. (2012) } \\ \text { Colombini et al. (2012) } & \text { Miyaji et al. (2013) } \\ \text { Davidson et al. (2003) } & \text { Miyaji et al. (2014) } \\ \text { De Campeneere et al. (2006) } & \text { Monteils et al. (2002) } \\ \text { De Campeneere et al. (2009) } & \text { Moorby and Theobald (1999) } \\ \text { Dewhurst et al. (2010) } & \text { Noftsger and St-Pierre (2003) } \\ \text { Eriksson et al. (2004) } & \text { Ramirez et al. (2012) } \\ \text { Ferris et al. (1999) } & \text { Ruiz et al. (2001) } \\ \text { Foley et al. (2006) } & \text { Ruiz et al. (2002) } \\ \text { Galo et al. (2003) } & \text { Sannes et al. (2002) } \\ \text { Gehman and Kononoff (2010) } & \text { Tas et al. (2006) } \\ \text { Gozho and Mutsvangwa (2008) } & \text { Tasja et al. (2011) } \\ \text { Gozho et al. (2008) } & \text { Vanhatalo et al. (2009) } \\ \text { Haig et al. (2002) } & \text { Wattiaux and Karg (2004) } \\ \text { Hassanat et al. (2013) } & \text { Whelan et al. (2011) } \\ \text { Higgs et al. (2013) } & \text { Wilkerson et al. (1997) } \\ \text { Hristov and Ropp (2003) } & \text { Wright et al. (1998) } \\ \text { Hristov et al. (2004) } & \text { Wright et al. (2003) } \\ \text { Kälber et al. (2012) } & \\ & \end{array}$

Kälber et al. (2012)

Fisher et al. (2000)

Heifers and nonlactating cows

Grimaud and Doreau (1995)

Hoffman et al. (2001)

Archibeque et al. (2007)

Cole et al. (2011)

Eisemann et al. (1989)

Elliott et al. (1997)

Fiems et al. (1997)

Gunun et al. (2013)

Hussein et al. (1996) error. The CCC was calculated using the epi.ccc function in the epiR package (Stevenson et al., 2014) in R statistical software ( $\mathrm{R}$ Core Group, Vienna, Austria) and is defined by the equation

$$
\rho_{c}=\frac{2 \sigma_{x y}}{\sigma_{x}^{2}+\sigma_{y}^{2}+\left(\mu_{y}-\mu_{x}\right)^{2}}
$$

where $\rho_{\mathrm{c}}$ represents the $\mathrm{CCC} ; \sigma_{\mathrm{xy}}$ is the covariance between the vectors of observed $(\mathbf{X})$ and predicted $(\mathbf{Y})$ values; $\sigma_{x}^{2}$ and $\sigma_{y}^{2}$ are the variances of vectors $\mathbf{X}$ and $\mathbf{Y}$; and $\mu_{x}$ and $\mu_{y}$ are the means of vectors $\mathbf{X}$ and $\mathbf{Y}$. The CCC combines measures of both precision and accuracy to determine how far the observed data deviate from the line of perfect concordance (a line at $45^{\circ}$ on a square scatter plot) with values close to 1 indicating agreement between observed and predicted (Lin, 1989, 2000). Like the RMSPE, the CCC can be decomposed to estimate a scale or slope shift $(v)$, location bias $(u)$ relative to scale shift, and a bias correction factor $\left(\mathrm{C}_{\mathrm{b}}\right)$ where values closer to 0 indicate less bias for $v$ and $u$ and values close to 1 indicate little to no deviation of the best fit line from the $45^{\circ}$ line.

Urinary $\mathrm{N}$ excretion in lactating cows was best predicted by Equations [1] and [6] (Table 3) based on values of RMPSE as a percentage of observed mean of $25.0 \%$ (Table 4). The CCC of Equation [6] was slightly larger than Equation [1]; however, the ED was larger in Equation [1] than in Equation [6]. The scale shift $(u)$ and location shift $(v)$ of the CCC were considerably greater in Equation [6] than Equation [1], which indicated Equation [6] had more bias, perhaps because Equation [6] requires 6 independent variables, and greater potential error from measurement and estimation of the input variables. Equations [12] and [15] had similar RMSPE and CCC values and both appear to predict FN well. Although Equation [15] requires fewer inputs, it performed as well as Equation [12]. Equations [18] and [19] had lowest RMSPE and CCC decomposition values in predicting TN. Both equations performed equally well despite Equation [19] requiring 5 more input variables compared with Equation [18]. Equations [26] and [27] were the best equations for predicting MN. Both Equations [26] and [27] performed well with RMSPE as a percentage of observed mean and CCC values of $14 \%$ and 0.73 vs. $15 \%$ and 0.81 , respectively. However, almost all error in Equation [26] came from random sources indicating little bias.

Equations for heifers and nonlactating cows consistently resulted in a large amount of bias in part due to the small number of observations available for 
Table 3. List of extant equations evaluated in this study ${ }^{1}$

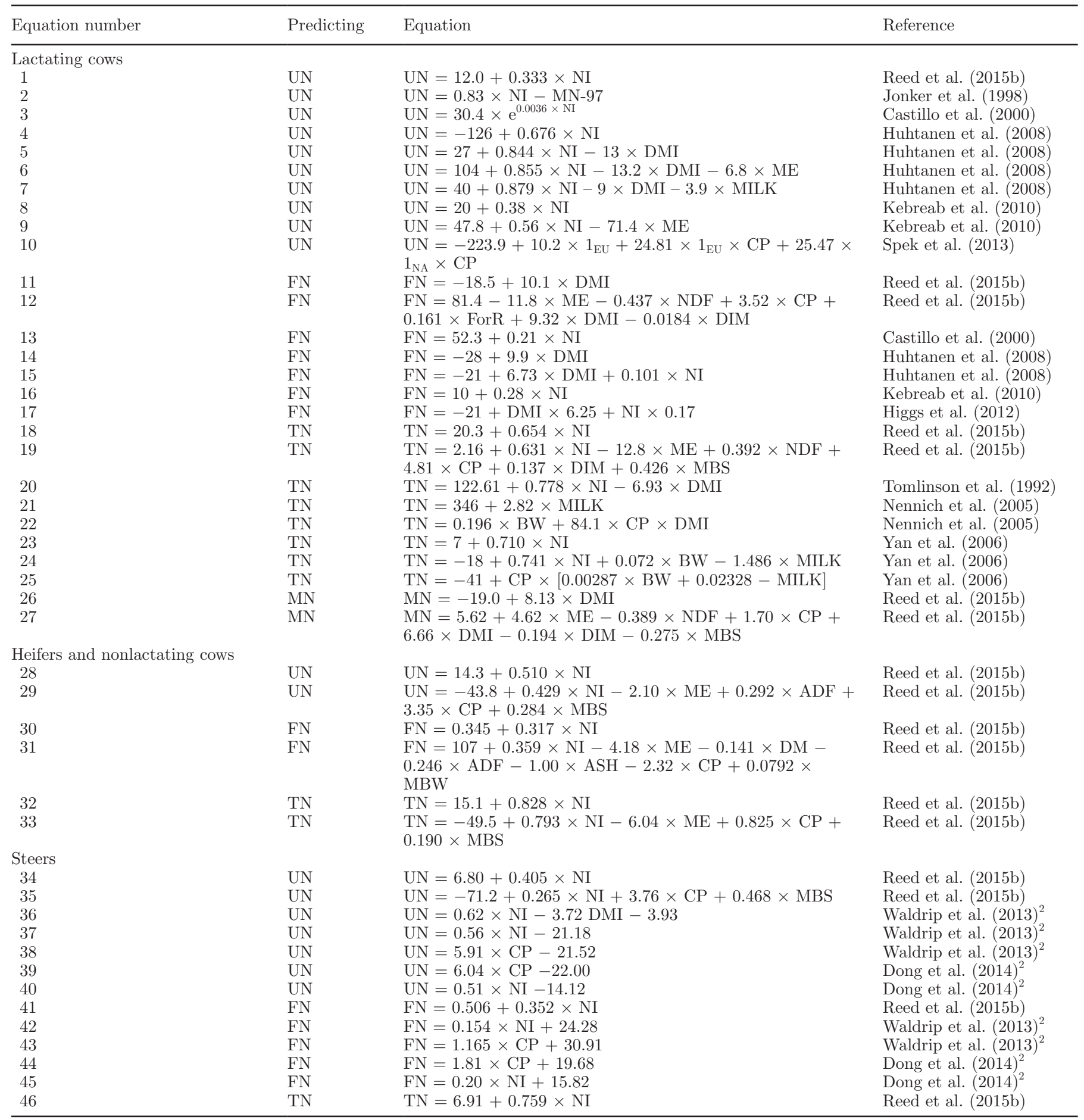

${ }^{1}$ Parameter estimates with standard errors in parentheses. UN $=$ urine nitrogen, $\mathrm{FN}=$ fecal nitrogen, $\mathrm{MN}=$ milk nitrogen, $\mathrm{TN}=$ total manure nitrogen, $\mathrm{NI}=$ nitrogen intake $(\mathrm{g} / \mathrm{d}), \mathrm{CP}(\%$ of DM), DE = digestible energy content $(\mathrm{kJ} / \mathrm{kg}$ of DM), NDF $(\%$ of DM), MBS = metabolic body size $\left(\mathrm{BW}^{3 / 4}, \mathrm{~kg}\right)$, DMI $(\mathrm{kg} / \mathrm{d}), \mathrm{ME}(\mathrm{kJ} / \mathrm{kg}), \mathrm{ADF}\left(\%\right.$ of DM), ForR = proportion of forage in the diet, ASH = ash content (\% of DM); $1_{\mathrm{EU}}$ and $1_{\mathrm{NA}}$ indicate whether the observation is from Europe or North America, respectively.

${ }^{2}$ Equations were developed and conducted on beef cattle. 
Table 4. Evaluation results using the root mean square prediction error (RMSPE), concordance correlation coefficient (CCC), and their decompositions ${ }^{1}$

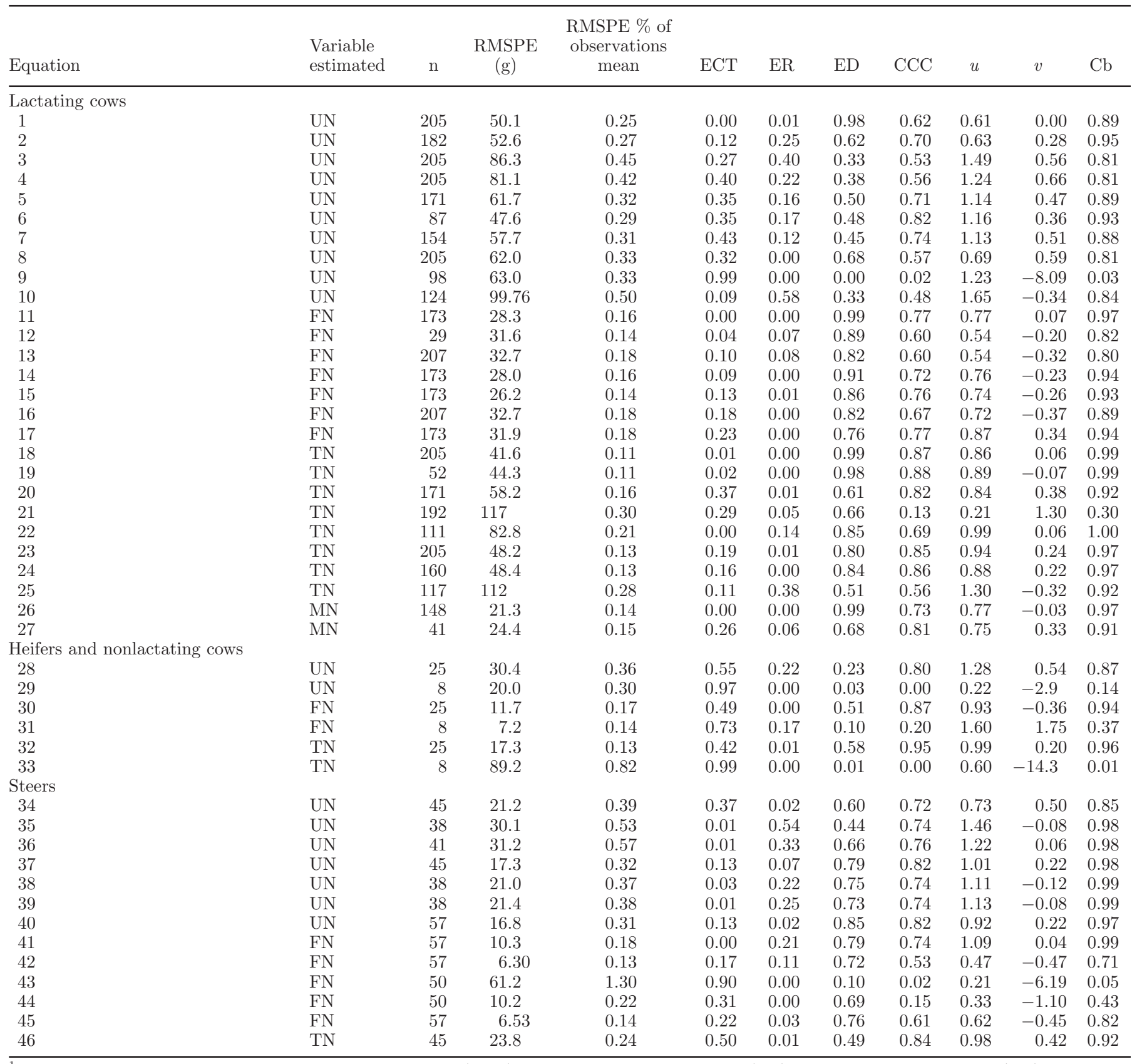

${ }^{1} \mathrm{RMSPE}$ decomposes into the error of central tendency (ECT), the error due to regression (ER), and the dispersion error (ED). The CCC decomposes into the scale shift $(v)$, the location shift $(u)$, and the bias correction factor $(\mathrm{Cb})$, fecal nitrogen (FN), urine nitrogen (UN), total nitrogen $(\mathrm{TN})$, milk nitrogen $(\mathrm{MN})$.

evaluation. More data are needed to better assess the predictive power of the equations. The simpler equations (Equations [28], [30], and [32]) consistently outperformed more complex equations (Equations [29], [31], and [33]) in predicting UN, FN, and TN in heifers and nonlactating cows. However, a limited amount of data was available to evaluate complex equations be- cause of their greater input requirements. Equations [37] and [40] performed well in predicting steer UN. However, Equation [40] had a slightly greater ED of $85 \%$ of RMSPE. Equations [42] and [45] both showed good predictive ability to predict steer FN with only slight differences in sources of error. Only Equation [46] estimated steer TN with RMSPE as a proportion of 
observed mean value of $24 \%$; however, $50 \%$ of error came from mean bias.

Irrespective of animal class, equations with fewer independent variables were evaluated with more observations (Table 4), which might have contributed to better performance compared with more complex equations. In several instances, increasing the number of independent variables did not improve predictive ability. In addition to the discrepancies in size of the evaluation data set, the varied performance of models with more input variables could be due to larger variation in the $\mathrm{N}$ excretion response to dietary factors beyond intake and CP content. For example, if the effect of increasing dietary fiber does not uniformly increase UN excretion in heifers and nonlactating cows across all the diets and feeding scenarios evaluated, then the addition of fiber to the prediction model would not increase model accuracy. In general, equations predicting TN had the lowest RMSPE and most of the error tended to be random in nature with minimal mean and slope biases. Urinary $\mathrm{N}$ typically had the most bias compared with other excretion forms. This could be due to several factors including (1) UN volatize quickly as $\mathrm{NH}_{3}$, which may result in underestimation of UN measurements; (2) UN is composed of several N-containing compounds including urea $\mathrm{N}$ and purine derivatives that originate predominantly from microbial $\mathrm{N}$ compounds, all of which are affected by different components of the diet contributing to variability (Dijkstra et al., 2013). Predictor variables that appeared consistently in the best performing models are NI and DMI. Biologically, $\mathrm{FN}$ is a direct function of NI and digestibility. More variation is present in UN for a given NI; however, as more $\mathrm{N}$ is ingested, $\mathrm{N}$ excretion in urine is expected to increase through many avenues including increased purine derivatives from an increase in microbial protein production, increased urea synthesis from increased absorption of $\mathrm{NH}_{3}$ across the rumen wall, and increased urea synthesis from amino acid oxidation especially as protein supply exceeds requirement. Crude protein content and ME also appear in several of the proposed equations but do not appear to contribute to prediction accuracy.

The equations developed by Reed et al. (2015b) for lactating cows resulted in less prediction error and bias compared with other extant equations evaluated here. The equation development procedure implemented by Reed et al. (2015b) differs from other studies in size and quality of the data used for equation development and the rigorous equation-selection process implemented. This process included a multistep, multilevel selection process to narrow down the number of potential equations followed by a genetic algorithm to select the best equation(s) from large pool of equations (Reed et al., 2015b). Other extant equations were developed from smaller data sets and used equation selection techniques, such as stepwise regression, that are subject to criticism (Reed et al., 2015a). Future equation selection and development should take advantage of advances in computing power and modern statistical approaches like the genetic algorithm illustrated by Reed et al. (2015b) in addition to knowledge of the biological significance of model inputs to advance the accuracy of $\mathrm{N}$ excretion prediction equations.

The equations evaluated here that demonstrated best predictive power for each animal class and form of excretion are recommended for use. For lactating dairy cattle, UN excretion was best predicted by Equation [1]. Equations [12] and [15] showed similar accuracy in predicting $\mathrm{FN}$; therefore, both equations are recommended for use, the choice of which depends on the availability of input variables. Similarly, Equations [18] and [19] had very close accuracy in predicting TN, so both are recommended. Equation [26] provided the best prediction power for $\mathrm{MN}$ and is recommended for use. For the heifers and nonlactating cow class, Equations [28], [30], and [32] are recommended for FN, UN, and $\mathrm{TN}$, respectively. In the steer animal class, the equations with the smallest amount of prediction error and bias were Equations [37] for UN, [42] and [45] for FN and [46] for TN; however, UN equations for steers did not perform well in general. Steer diets can have highly variable compositions ranging from $100 \%$ forage to $80 \%$ concentrate and $20 \%$ forage. This wide range of ingredients could contribute to the poor predictive ability of the UN models, especially if the development data did not span the same ingredient range as the evaluation data. Although sufficient data are available on lactating dairy cows, there is a paucity of $\mathrm{N}$ balance studies on heifers and nonlactating cows. The generally lower prediction accuracy from equations for heifers and nonlactating cows could be in part due to the small amount of data available for equation development and evaluation. It is recommended that more data be collected on heifers and nonlactating so that better equations can be developed and more thoroughly evaluated. Our results show that $\mathrm{N}$ equations have a better predictive power if the equations were developed from larger data sets and if sufficient data are available with which to evaluate the equations. Although, ideally prediction equations are expected to perform well on all data, an evaluation data set should be large enough to capture the equation's performance over a variety of input scenarios. In small evaluation data sets, observations that may be outliers can have an unduly large effect on the assessment of the equation's predictive ability. To assess 
whether an evaluation data set is sufficiently large, one can employ a power analysis to see if enough data are available to detect if the difference between observed and predicted $(D)$ values is within a certain range of the mean. Such a test applied to Equation [30] using $\alpha$ $=0.05$, and testing for the ability to detect prediction accuracy within $10 \%$ of the mean would only have a power of 0.8 or above if the true mean of $D$ is within $4.8 \%$ of the mean observed values for FN. To detect a difference of $10 \%$ or less of the mean with a power of 0.8 or greater, at least 40 observations would be needed to evaluate Equation [30].

The predictive equations of UN and FN for the lactating cow and heifers and nonlactating animal classes performed well: less than $30 \%$ and $20 \%$ prediction error, respectively. Because excreted $\mathrm{N}$ sources affect downstream estimates of potential pollutants such as $\mathrm{NH}_{3}$ and $\mathrm{N}_{2} \mathrm{O}$, using specific equations for UN and $\mathrm{FN}$ could improve assessment of $\mathrm{N}$ emissions from cattle production facilities. Volatilization of $\mathrm{NH}_{3}$ from urinary urea- $\mathrm{N}$ is the main source of $\mathrm{N}$ that affects air quality, whereas FN and other UN compounds are more likely to contribute to $\mathrm{N}$ overload in the soil. Thus, the origin of the excretion should be taken into consideration in the effort to determine how $\mathrm{N}$ lost from dairy production facilities affects the ecosystem.

In conclusion, mathematical equations evaluated in this study could be used to assess mitigation strategies that are aimed in reducing $\mathrm{N}$ pollution from cattle facilities and improve national and international inventories for accounting greenhouse gas emissions, especially $\mathrm{N}_{2} \mathrm{O}$. Equations that partition $\mathrm{N}$ excretion into urine and fecal origin are useful in estimating $\mathrm{N}$ emissions to air or $\mathrm{N}$ potentially available for plant uptake and leaching to ground water. Equations developed with large amount of data and employ state-of-the-art statistical techniques were among the best predictors of $\mathrm{N}$ excretion in this study.

\section{ACKNOWLEDGMENTS}

The authors thank the UC Davis Sesnon Endowed Chair program, the UC Davis Lyons Fellowship program, and Ajinomoto Heartland (Chicago, IL) for their support of this project.

\section{REFERENCES}

Agle, M., A. N. Hristov, S. Zaman, C. Schneider, P. Ndegwa, and V. K. Vaddella. 2010a. Effect of dietary concentrate on rumen fermentation, digestibility, and nitrogen losses in dairy cows. J. Dairy Sci. 93:4211-4222.

Agle, M., A. N. Hristov, S. Zaman, C. Schneider, P. Ndegwa, and V. K. Vaddella. 2010b. The effects of ruminally degraded protein on ru- men fermentation and ammonia losses from manure in dairy cows. J. Dairy Sci. 93:1625-1637.

Archibeque, S. L., H. C. Freetly, N. A. Cole, and C. L. Ferrell. 2007. The influence of oscillating dietary protein concentrations on finishing cattle. II. Nutrient retention and ammonia emissions. J. Anim. Sci. 85:1496-1503.

Arriaga, H., G. Salcedo, L. Martinez-Suller, S. Calsamiglia, and P. Merino. 2010. Effect of dietary crude protein modification on ammonia and nitrous oxide concentration on a tie-stall dairy barn floor. J. Dairy Sci. 93:3158-3165.

Aschemann, M., P. Lebzein, L. Hüther, S. Döll, K. Südekum, and S. Dänicke. 2012. Effect of niacin supplementation on digestibility, nitrogen utilisation and milk and blood variables in lactating dairy cows fed a diet with a negative rumen nitrogen balance. Arch. Anim. Nutr. 66:200-214.

Beckman, J. L., and W. P. Weiss. 2005. Nutrient digestibility of diets with different fiber to starch ratios when fed to lactating dairy cows. J. Dairy Sci. 88:1015-1023.

Benchaar, C., F. Hassanat, R. Gervais, P. Y. Chouinard, C. Julien, H. V. Petit, and D. I. Massé. 2013. Effects of increasing amounts of corn dried distillers grains with solubles in dairy cow diets on methane production, ruminal fermentation, digestion, nitrogen balance, and milk production. J. Dairy Sci. 96:2413-2427.

Benchaar, C., F. Hassanat, R. Gervais, P. Y. Chouinard, H. V. Petit, and D. I. Massé. 2014. Methane production, digestion, ruminal fermentation, nitrogen balance, and milk production of cows fed corn silage- or barley silage-based diets. J. Dairy Sci. 97:961-974.

Bibby, J., and H. Toutenburg. 1977. Prediction and Improved Estimation in Linear Models. John Wiley and Sons, London, UK.

Borucki Castro, S. I., L. E. Phillip, H. Lapierre, P. W. Jardon, and R. Berthiaume. 2008. The relative merit of ruminal undegradable protein from soybean meal or soluble fiber from beet pulp to improve nitrogen utilization in dairy cows. J. Dairy Sci. 91:3947-3957.

Castillo, A. R., E. Kebreab, D. E. Beever, J. H. Barbi, J. D. Sutton, H. C. Kirby, and J. France. 2001. The effect of energy supplementation on nitrogen utilization in lactating dairy cows fed grass silage diets. J. Anim. Sci. 79:240-246.

Castillo, A. R., E. Kebreab, D. E. Beever, and J. France. 2000. A review of efficiency of nitrogen utilisation in lactating dairy cows and its relationship with environmental pollution. J. Anim. Feed Sci. 9:1-32.

Chen, Z. H., G. A. Broderick, and M. K. Clayton. 2011. Effect of feeding different sources of rumen-protected methionine on milk production and N-utilization in lactating dairy cows. J. Dairy Sci. 94:1978-1988.

Cherney, D. J. R., J. H. Cherney, and L. E. Chase. 2003. Influence of dietary nonfiber carbohydrate concentration and supplementation of sucrose on lactation performance of cows fed fescue silage. J. Dairy Sci. 86:3983-3991.

Chibisa, G. E., G. N. Gosho, A. G. Van Kessel, A. A. Olkowski, and T. Mutsvangwa. 2008. Effects of peripartum propylene glycol supplementation on nitrogen metabolism, body composition, and gene expression for the major protein degradation pathways in skeletal muscle in dairy cows. J. Dairy Sci. 91:3512-3527.

Cole, N. A., K. McCuistion, L. W. Greene, and F. T. McCollum. 2011. Effects of concentration and source of wet distillers grains on digestibility of steam-flaked corn-based diets fed to finishing steers. Prof. Anim. Sci. 27:302-311.

Colombini, S., G. Galassi, G. M. Crovetto, and L. Rapetti. 2012. Milk production, nitrogen balance, and fiber digestibility prediction of corn, whole plant grain sorghum, and forage sorghum silages in the dairy cow. J. Dairy Sci. 95:4457-4467.

Davidson, E. A. 2009. The contribution of manure and fertilizer nitrogen to atmospheric nitrous oxide since 1860. Nat. Geosci. 2:659662 .

Davidson, S., B. A. Hopkins, D. Diaz, S. M. Bolt, C. Brownie, and V. Fellner. 2003. Effects of amounts and degradability of dietary protein on lactation, nitrogen utilization, and excretion in early lactation Holstein cows. J. Dairy Sci. 86:1681-1689. 
De Campeneere, S., J. L. De Boever, J. M. Vanacker, W. Messens, and D. L. De Brabander. 2009. Feeding measures to reduce nitrogen excretion in dairy cattle. Arch. Anim. Nutr. 63:87-103.

De Campeneere, S., D. L. De Brabander, and J. M. Vanacker. 2006. Milk urea concentration as affected by the roughage type offered to dairy cattle. Livest. Sci. 103:30-39.

Dewhurst, R. J., L. J. Davies, and E. J. Kim. 2010. Effects of mixtures of red clover and maize silages on the partitioning of dietary nitrogen between milk and urine by dairy cows. Animal 4:732-738.

Diaz, R. J., and R. Rosenberg. 2008. Spreading dead zones and consequences for marine ecosystems. Science 321:926-929.

Dijkstra, J., O. Oenema, J. W. van Groenigen, J. W. Spek, A. M. van Vuuren, and A. Bannink. 2013. Diet effects on urine composition of cattle and $\mathrm{N}_{2} \mathrm{O}$ emissions. Animal 7(Suppl. 2):292-302.

Dong, R. L., G. Y. Zhao, L. L. Chai, and K. A. Beauchemin. 2014 Prediction of urinary and fecal nitrogen excretion by beef cattle. J. Anim. Sci. 92:4669-4681.

Eisemann, J. H., A. C. Hammond, T. S. Rumsey, and D. E. Bauman. 1989. Nitrogen and protein metabolism and metabolites in plasma and urine of beef steers treated with somatotropin. J. Anim. Sci. 67:105-115.

Elliott, J. P., J. K. Drackley, C. G. Aldrich, and N. R. Merchen. 1997. Effects of saturation and esterification of fat sources on site and extent of digestion in steers: Ruminal fermentation and digestion of organic matter, fiber, and nitrogen. J. Anim. Sci. 75:2803-2812.

EPA. 2014. Inventory of U.S. Greenhouse Gas Emissions and Sinks: 1990-2012. United States Environmental Protection Agency (EPA), Washington, DC. Accessed Jul. 1, 2015. http://www.epa. gov/climatechange/emissions/usinventoryreport.html.

Eriksson, T., M. Murphy, P. Ciszuk, and E. Burstedt. 2004. Nitrogen balance, microbial protein production, and milk production in dairy cows fed fodder beets and potatoes, or barley. J. Dairy Sci. 87:1057-1070

Ferris, C. P., F. J. Fordon, D. C. Patterson, M. G. Porter, and T. Yan. 1999. The effect of genetic merit and concentrate proportion in the diet on nutrient utilization by lactating dairy cows. J. Agric. Sci. 132:483-490

Fiems, L. O., B. G. Cottyn, Ch. V. Boucqué, D. F. Bogaerts, C. Van Eenaeme, and J. M. Vanacker. 1997. Effect of beef type, body weight and dietary protein content on voluntary feed intake, digestibility, blood and urine metabolites and nitrogen retention. J. Anim. Physiol. Anim. Nutr. (Berl.) 77:1-9.

Fisher, L. J., N. E. Dinn, J. A. Shelford, and J. W. Paul. 2000. The effect of concentration and form of dietary nitrogen on the utilization and excretion of nitrogen by lactating dairy cows. Can. J. Anim. Sci. 80:207-209.

Foley, A. E., A. N. Hristov, A. Melgar, J. K. Ropp, R. P. Etter, S. Zaman, C. W. Hunt, K. Huber, and W. J. Price. 2006. Effect of barley and its amylopectin content on ruminal fermentation and nitrogen utilization in lactating dairy cows. J. Dairy Sci. 89:43214335.

Fowler, D., M. Coyle, U. Skiba, M. A. Sutton, J. N. Cape, S. Reis, L. J. Sheppard, A. Jenkins, B. Grizzetti, J. N. Galloway, P. Vitousek, A. Leach, A. F. Bouwman, K. Butterback-Bahl, F. Dentener, D. Stevenson, M. Amann, and M. Voss. 2013. The global nitrogen cycle in the twenty-first century. Phil. Trans. R. Soc. Lond. B Biol. Sci. 368:20130164. http://dx.doi.org/10.1098/rstb.2013.0164.

Galo, E., S. M. Emanuele, C. J. Sniffen, J. H. White, and J. R. Knapp. 2003. Effects of a polymer-coated urea product on nitrogen metabolism in lactating Holstein dairy cattle. J. Dairy Sci. 86:2154-2162.

Gehman, A. M., and P. J. Kononoff. 2010. Utilization of nitrogen in cows consuming wet distillers grains with solubles in alfalfa and corn silage-based dairy rations. J. Dairy Sci. 93:3166-3175.

Gerber, P. J., H. Steinfeld, B. Henderson, A. Mottet, C. Opio, J. Dijkman, A. Falcucci, and G. Tempio. 2013. Tackling climate change through livestock-A global assessment of emissions and mitigation opportunities. Food and Agriculture Organization of the United Nations, Rome, Italy.

Gozho, G. N., M. R. Hobin, and T. Mutsvangwa. 2008. Interactions between barley grain processing and source of supplemental di- etary fat on nitrogen metabolism and urea-nitrogen recycling in dairy cows. J. Dairy Sci. 91:247-259.

Gozho, G. N., and T. Mutsvangwa. 2008. Influence of carbohydrate source on ruminal fermentation characteristics, performance, and microbial protein synthesis in dairy cows. J. Dairy Sci. 91:27262735.

Grimaud, P., and M. Doreau. 1995. Effect of extended underfeeding on digestion and nitrogen balance in nonlactating cows. J. Anim. Sci. 73:211-219.

Gunun, P., M. Wanapat, and N. Anantasook. 2013. Effects of physical form and urea treatment of rice straw on rumen fermentation, microbial protein synthesis and nutrient digestibility in dairy steers. Asian-australas. J. Anim. Sci. 26:1689-1697.

Haig, P. A., T. Mutsvangwa, R. Spratt, and B. W. McBride. 2002. Effects of dietary protein solubility on nitrogen losses from lactating dairy cows and comparison with predictions from the Cornell net carbohydrate and protein system. J. Dairy Sci. 85:1208-1217.

Hassanat, F., R. Gervais, C. Julien, D. I. Massé, A. Lettat, and P. Y. Chouinard. 2013. Replacing alfalfa silage with corn silage in dairy cow diets: Effects on enteric methane production, ruminal fermentation, digestion, $\mathrm{N}$ balance, and milk production. J. Dairy Sci. 96:4553-4567.

Higgs, R. J., L. E. Chase, and M. E. Van Amburgh. 2012. Development and evaluation of equations in the Cornell Net Carbohydrate and Protein System to predict nitrogen excretion in lactating dairy cows. J. Dairy Sci. 95:2004-2014.

Higgs, R. J., A. J. Sheahan, K. Mandok, M. E. Van Amburgh, and J. R. Roche. 2013. The effect of starch-, fiber-, or sugar-based supplements on nitrogen utilization in grazing dairy cows. J. Dairy Sci. 96:3857-3866.

Hoffman, P. C., N. M. Esser, L. M. Bauman, S. L. Denzine, M. Engstrom, and H. Chester-Jones. 2001. Short Communication: Effect of dietary protein on growth and nitrogen balance of Holstein heifers. J. Dairy Sci. 84:843-847.

Hristov, A. N., K. L. Grandeen, J. K. Ropp, and M. A. McGuire. 2004 Effect of sodium laurate on ruminal fermentation and utilization of ruminal ammonia nitrogen for milk protein synthesis in dairy cows. J. Dairy Sci. 87:1820-1831.

Hristov, A. N., and J. K. Ropp. 2003. Effect of dietary carbohydrate composition and availability on utilization of ruminal ammonia nitrogen for milk protein synthesis in dairy cows. J. Dairy Sci. $86: 2416-2427$

Huhtanen, P., J. I. Nousiainen, M. Rinne, K. Kyto, and H. Khalili. 2008. Utilization and partition of dietary nitrogen in dairy cows fed grass silage-based diets. J. Dairy Sci. 91:3589-3599.

Hussein, H. S., N. R. Merchen, and G. C. Fahey. 1996. Effects of forage percentage and canola seed on ruminal protein metabolism and duodenal flows of amino acids in steers. J. Dairy Sci. 79:98-104.

IPCC. 2006. 2006 IPCC Guidelines for National Greenhouse Gas Inventories. Intergovernmental Panel on Climate Change: Institute for Global Environmental Strategies, Hayama, Japan.

Jonker, J. S., R. A. Kohn, and R. A. Erdman. 1998. Using milk urea nitrogen to predict nitrogen excretion and utilization efficiency in lactating dairy cows. J. Dairy Sci. 81:2681-2692.

Kälber, T., M. Kreuzer, and F. Leiber. 2012. Silages containing buckwheat and chicory: Quality, digestibility and nitrogen utilisation by lactating cows. Arch. Anim. Nutr. 66:50-65.

Kamiya, M., Y. Iwama, M. Tanaka, and S. Shioya. 2005. Effects of high ambient temperature and restricted feed intake on nitrogen utilization for milk production in lactating Holstein cows. Anim. Sci. J. 76:217-223.

Kang, S., M. Wanapat, and A. Cherdthorng. 2014. Effect of banana flower powder supplementation as a rumen buffer on rumen fermentation efficiency and nutrient digestibility in dairy steers fed a high-concentrate diet. Anim. Feed Sci. Technol. 196:32-41.

Kauffman, A. J., and N. R. St-Pierre. 2001. The relationship of milk urea nitrogen to urine nitrogen excretion in Holstein and Jersey cows. J. Dairy Sci. 84:2284-2294.

Kebreab, E., A. B. Strathe, J. Dijkstra, J. A. N. Mills, C. K. Reynolds, L. A. Crompton, T. Yan, and J. France. 2010. Energy and protein interactions and their effect on nitrogen excretion in dairy cows. 
Pages 417-425 in Proc. 3rd EAAP International Symposium on Energy and Protein Metabolism. M. Crovetto, ed. Wageningen Publishers, Wageningen, the Netherlands.

Kolver, E., L. D. Muller, G. A. Varga, and T. J. Cassidy. 1998. Synchronization of ruminal degradation of supplemental carbohydrate with pasture nitrogen in lactating dairy cows. J. Dairy Sci. 81:2017-2028.

Korhonen, M., A. Vanhatalo, and P. Huhtanen. 2002. Effect of protein source on amino acid supply, milk production, and metabolism of plasma nutrients in dairy cows fed grass silage. J. Dairy Sci. 85:3336-3351.

Kröber, T. F., D. R. Külling, H. Menzi, F. Sutter, and M. Kreuzer. 2000. Quantitative effects of feed protein reduction and methionine on nitrogen use by cows and nitrogen emission from slurry. J. Dairy Sci. 83:2941-2951.

Lapierre, H., J. P. Blouin, J. F. Bernier, C. K. Reynolds, P. Dubreuil, and G. E. Lobley. 2002. Effect of supply of metabolizable protein on whole body and splanchnic leucine metabolism in lactating dairy cows. J. Dairy Sci. 85:2631-2641.

Lascano, G. J., and A. J. Heinrichs. 2011. Effects of feeding different levels of dietary fiber through the addition of corn stover on nutrient utilization of dairy heifers precision-fed high and low concentrate diets. J. Dairy Sci. 94:3025-3036.

Lee, C., A. N. Hristov, K. S. Heyler, T. W. Cassidy, M. Long, B. A. Corl, and S. K. R. Karnati. 2011. Effects of dietary protein concentration and coconut oil supplementation on nitrogen utilization and production in dairy cows. J. Dairy Sci. 94:5544-5557.

Lee, M. R. F., V. J. Theobald, J. K. S. Tween, A. L. Winters, and N. D. Scollan. 2009. Effect of feeding fresh or conditioned red clover on milk fatty acids and nitrogen utilization in lactating dairy cows. J. Dairy Sci. 92:1136-1147.

Lehloenya, K. V., C. R. Krehbiel, K. J. Mertz, T. G. Rehberger, and L. J. Spicer. 2008. Effects of propionibacteria and yeast culture fed to steers on nutrient intake and site and extent of digestion. J. Dairy Sci. 91:653-662.

Leiva, E., M. B. Hall, and H. H. Van Horn. 2000. Performance of dairy cattle fed citrus pulp or corn products as sources of neutral detergent-soluble carbohydrates. J. Dairy Sci. 83:2866-2875.

Lin, L. 1989. A concordance correlation coefficient to evaluate reproducibility. Biometrics 45:255-268.

Lin, L. 2000. A note on the concordance correlation coefficient. Biometrics 56:324-325.

Marini, J. C., and M. E. Van Amburgh. 2003. Nitrogen metabolism and recycling in Holstein heifers. J. Anim. Sci. 81:545-552.

McCubbin, D. R., B. J. Apelberg, S. Roe, and F. Divita. 2002. Livestock ammonia management and particulate-related health benefits. Environ. Sci. Technol. 36:1141-1146.

Mitani, T., M. Takahashi, K. Ueda, H. Nakatsuji, and S. Kondo. 2005. Effects of pre-feeding of a corn silage-based supplement on the feed intake, milk production and nitrogen utilization of grazing dairy cows. Anim. Sci. J. 76:453-460

Mitsuru, K., Y. Iwama, M. Tanaka, and S. Shioya. 2005. Effects of high ambient temperature and restricted feed intake on nitrogen utilization for milk production in lactating Holstein cows. Anim. Sci. J. 76:217-223.

Miyaji, M., H. Matsuyama, and K. Hosoda. 2014. Effect of substituting brown rice for corn on lactation and digestion in dairy cows fed diets with a high proportion of grain. J. Dairy Sci. 97:952-960.

Miyaji, M., H. Matsuyama, K. Hosoda, and K. Nonaka. 2012. Effect of replacing corn with brown rice grain in a total mixed ration silage on milk production, ruminal fermentation and nitrogen balance in lactating dairy cows. Anim. Sci. J. 83:585-593.

Miyaji, M., H. Matsuyama, K. Hosoda, and K. Nonaka. 2013. Milk production, nutrient digestibility and nitrogen balance in lactating cows fed total mixed ration silages containing steam-flaked brown rice as substitute for steam-flaked corn, and wet food by-products. Anim. Sci. J. 84:483-488.

Monteils, V., S. Jurjanz, G. Blanchart, and F. Laurent. 2002. Nitrogen utilisation by dairy cows fed diets differing in crude protein level with a deficit in ruminal fermentable nitrogen. Reprod. Nutr. Dev. $42: 545-557$.
Moorby, J. M., P. Robinson, W. J. Fisher, and R. T. Evans. 2008. Comparison of red clover and ryegrass silage for dry cows and influence on subsequent lactation performance. J. Dairy Sci. 91:3501-3511.

Moorby, J. M., and V. J. Theobald. 1999. Short Communication: The effect of duodenal ammonia infusions on milk production and nitrogen balance of the dairy cow. J. Dairy Sci. 82:2440-2442.

Nennich, T. D., J. H. Harrison, L. M. VanWieringen, D. Meyer, A. J. Heinrichs, W. P. Weiss, N. R. St-Pierre, R. L. Kincaid, D. L. Davidson, and E. Block. 2005. Prediction of manure and nutrient excretion from dairy cattle. J. Dairy Sci. 88:3721-3733.

Noftsger, S., and N. R. St-Pierre. 2003. Supplementation of methionine and selection of highly digestible rumen undegradable protein to improve nitrogen efficiency for milk production. J. Dairy Sci. $86: 958-969$.

NRC. 2001. Nutrient Requirements of Dairy Cattle. 7th rev. ed. Natl. Acad. Sci., Washington, DC.

Piao, M. Y., H. J. Kim, J. K. Seo, T. S. Park, J. S. Yoon, K. H. Kim, and J. K. Ha. 2012. Effects of synchronization of carbohydrate and protein supply in total mixed ration with Korean tice wine residue on ruminal fermentation, nitrogen metabolism and microbial protein synthesis in Holstein steers. Asian-australas. J. Anim. Sci. $25: 1568-1574$.

Ramirez, H. A. R., K. Nestor, L. O. Tedeschi, T. R. Callaway, S. E. Dowd, S. C. Fernando, and P. J. Kononoff. 2012. The effect of brown midrib corn silage and dried distillers' grains with solubles on milk production, nitrogen utilization and microbial community structure in dairy cows. Can. J. Anim. Sci. 92:365-380.

Reed, K. F., D. P. Casper, J. France, and E. Kebreab. 2015a. Prediction of nitrogen efficiency in dairy cattle: A review. CAB Reviews. 10:1-12.

Reed, K. F., L. E. Moraes, D. P. Casper, and E. Kebreab. 2015b. Predicting nitrogen excretion from cattle. J. Dairy Sci. 98:3025-3035.

Ruiz, R., G. L. Albrecht, L. O. Tedeschi, G. Jarvis, J. B. Russell, and D. G. Fox. 2001. Effect of monensin on the performance and nitrogen utilization of lactating dairy cows consuming fresh forage. J. Dairy Sci. 84:1717-1727.

Ruiz, R., L. O. Tedeschi, C. Marini, D. G. Fox, A. N. Pell, and G. Jarvis. 2002. The effect of a ruminal nitrogen (N) deficiency in dairy cows: Evaluation of the Cornell Net Carbohydrate and Protein System ruminal N deficiency adjustment. J. Dairy Sci. 85:29862999.

Sannes, R. A., M. A. Messman, and D. B. Vagnoni. 2002. Form of rumen-degradable carbohydrate and nitrogen on microbial protein synthesis and protein efficiency of dairy cows. J. Dairy Sci. 85:900-908.

Spek, J., J. Dijkstra, G. V. Duinkerken, W. Hendriks, and A. Bannink. 2013. Prediction of urinary nitrogen and urinary urea nitrogen excretion by lactating dairy cattle in northwestern Europe and North America: A meta-analysis. J. Dairy Sci. 96:4310-4322.

Spiehs, M. J., and V. H. Varel. 2009. Nutrient excretion and odorant production in manure from cattle fed corn wet distillers grains with solubles. J. Anim. Sci. 87:2977-2984.

Stevenson, M., T. Nunes, C. Heuer, J. Marshall, J. Sanchez, R. Thornton, J. Reiczigel, J. Robison-Cox, P. Sebastiani, P. Solymos, and K. Yoshida. 2014. epiR: An R package for the analysis of epidemiological data. R package version 0.9-57. http://CRAN.R-project. org $/$ package $=$ epiR .

Tas, B. M., H. Z. Taweel, H. J. Smit, A. Elgersma, J. Dijkstra, and S. Tamminga. 2006. Utilisation of $\mathrm{N}$ in perennial ryegrass cultivars by stall-fed lactating dairy cows. Livest. Sci. 100:159-168.

Tasja, K., M. Kreuzer, and F. Leiber. 2012. Silages containing buckwheat and chicory: Quality digestibility and nitrogen utilisation by lactating cows. Arch. anim. Nut. 66:50-65.

Tomlinson, A. P., H. H. Van Horn, R. A. Nordstedt, and C. J. Wilcox. 1992. Prediction of nitrogen excretion based on diet composition and performance criteria. J. Dairy Sci. 75(Suppl. 1):176. (Abstr.)

Valkeners, D., A. Théwis, M. Van Laere, and Y. Beckers. 2008. Effect of rumen-degradable protein balance deficit on voluntary intake, microbial protein synthesis, and nitrogen metabolism in growing 
double-muscled Belgian Blue bulls fed corn silage-based diet. J. Anim. Sci. 86:680-690.

Vanhatalo, A., K. Kuoppala, S. Ahvenjarvi, and M. Rinne. 2009. Effects of feeding grass or red clover silage cut at two maturity stages in dairy cows. 1. Nitrogen metabolism and supply of amino acids. J. Dairy Sci. 92:5620-5633.

Waggoner, J. W., C. A. Löest, J. L. Turner, C. P. Mathis, and D. M. Halford. 2009. Effects of dietary protein and bacterial lipopolysaccharide infusion on nitrogen metabolism and hormonal responses of growing beef steers. J. Anim. Sci. 87:3656-3668.

Waldrip, H. M., R. W. Todd, and N. A. Cole. 2013. Prediction of nitrogen excretion by beef cattle: A meta-analysis. J. Anim. Sci. 91:4290-4302.

Wattiaux, M. A., and K. L. Karg. 2004. Protein level for alfalfa and corn silage-based diets: II. Nitrogen balance and manure characteristics. J. Dairy Sci. 87:3492-3502.

Whelan, S. J., F. J. Mulligan, B. Flynn, C. McCarney, and K. M. Pierce. 2011. Effect of forage source and a supplementary methio- nine hydroxy analog on nitrogen balance in lactating dairy cows offered a low crude protein diet. J. Dairy Sci. 94:5080-5089.

Wilkerson, V. A., B. P. Glenn, and K. R. Mcleod. 1997. Energy and nitrogen balance in lactating cows fed diets containing dry or high moisture corn in either rolled or ground form. J. Dairy Sci. 80:2487-2496.

Wright, T. C., B. J. Holub, A. R. Hill, and B. W. McBride. 2003. Effect of combinations of fish meal and feather meal on milk fatty acid content and nitrogen utilization in dairy cows. J. Dairy Sci. 86:861-869.

Wright, T. C., S. Moscardini, P. H. Luimes, and B. W. McBride. 1998 Effects of rumen-undegradable protein and feed intake on nitrogen balance and milk protein production in dairy cows. J. Dairy Sci. 81:784-793.

Yan, T., J. P. Frost, R. E. Agnew, R. C. Binnie, and C. S. Mayne. 2006. Relationships among manure nitrogen output and dietary and animal factors in lactating dairy cows. J. Dairy Sci. 89:3981-3991. 